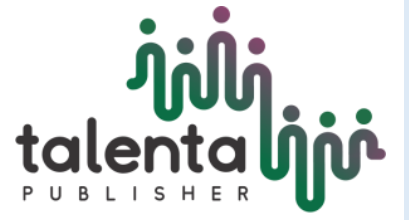

Intepnational doupmal of Ecophysiology

\title{
ISOLATION AND CHARACTERIZATION OF SULFUR-OXIDIZING BACTERIA (SOB) FROM WASTE OF RUBBER FACTORY AND PAPER IN JAMBI
}

\author{
Suparjo $^{1 *}$ Ummi Mardhiah Batubara ${ }^{1}$ Endah Rosa ${ }^{2}$, Nurhayati ${ }^{2}$, \\ Miratunnisa ${ }^{2}$
}

1,2 Study Program of Biology, Faculty of Science and Technology, University of Jambi, Jl. Jambi MaBulian, Postal Code 36361 Indonesia

\begin{abstract}
Sewage contains high concentration of sulfate and contaminates ground water supply. The production process in the factory produced sewage containing high amount of sulfur such as sulphide and sulphate. Sulfur bacteria, which are capable of oxidizing, reducing or partially oxidizing inorganic sulfur compounds such as Thiomicrospira, Thiothrix, Desulforomonas, Achromatium, and a group of Thiobacillus. Utilization of sulfur bacteria has done in attemp to find sewage bioremediation agents as well as to promote soil fertility. Isolation and characterization were carried out by growing the bacteria in the starkey selective medium, including $\mathrm{pH}$ reduction test, morphology, physiology and biochemical characterization. It has been observed that out of 2 isolates from different sources of samples (rubber and paper sewage), only one isolates related to sulfur-oxidizing bacterium (SOB) while the isolates AE01 related to true sulfur-oxidizing bacterium in genus Thiobacillus.
\end{abstract}

Keywords: bioremediation agent, sewage liquid, sulfur oxidizing bacteria (SOB), Thiobacillus

R Received 1 July 2019 | Revised 20 August 2019| Accepted 31 August 2019

\section{Introduction}

Factory waste contains high concentrations of sulfate which flows from sulfide-rich spots. Contamination of groundwater supply from factory waste can cause disruption to aquatic flora and fauna, corrosion of flow pipes and bridges, destruction of roads, etc. (Sajjad et al. 2016).

\footnotetext{
*Corresponding author at: University of Jambi, Jl. Jambi Ma-Bulian, Postal Code 36361 Indonesia

E-mail address: ummimardhiahbb@unja.ac.id 
The production process at rubber and paper factories produces waste containing large amounts of sulfur compounds such as sulfides and sulfates. Some additional compounds such as TMTD (tetramethyl triuram disulphide), sodium sulphide, ammonia (NH3) and sulfuric acid are also used (Kantachote and Innuwat, 2004; Nurhayati \& Mahmudin, 2012).

Sulfur bacteria consist of groups of heterogeneous organisms that have the ability to oxidize, reduce or partially oxidize inorganic sulfur compounds (Priyanka, Sivaji and Sridar, 2014). In addition to playing a role in increasing soil fertility through sulfur oxidation and solubilization of plant nutrients, sulfur bacteria can also be used as bioremediation agents for sulfur-containing wastes (Rojas-Avelizapa et al. 2013).

Sulfur bacteria can live in $\mathrm{pH}$ with a range of 1.0 - 10.5 (Priyanka, Sivaji and Sridar, 2014). Sulfur bacteria usually live in acidic environments such as soil containing a lot of sulfur (rhizosfir soil), factory waste and ex-mine land, and used tannery water (Vidyalakshmi and Sridar, 2006).

This study aims to isolate sulfur-oxidizing bacteria ( $\mathrm{SOB}$ ) from rubber and paper waste and characterize to determine the species of sulfur bacteria isolated from rubber and paper waste. The isolated SOB bacteria are used for alkaline soil reclamation, increasing sulfur oxidation in the soil as well as bioremediation agents for sulfur-containing wastes.

\section{Sampling}

The isolates of sulfur-oxidizing autotrophic bacteria were taken from 2 different sources which were rubber waste from rubber factories located in Batanghari Regency, Jambi Province and paper waste taken from paper mills located in Sabak, Tanjung Jabung Timur Regency, Jambi Province. The rubber waste samples taken wre black while the rubber waste samples are golden clear. Rubber and paper waste samples were then measured for $\mathrm{pH}$ and electrical conductivity.

\section{Media Preparation and Bacterial Isolation}

The media used for isolating SOB bacteria is the Thiobacillus broth media which is a modification of the Starkey media, with a composition of $0.40 \mathrm{gr}$ (NH4) 2SO4, 4.0 gr KH2PO4, 0.25 gr CaCl.2H2O, 0.01 gr FeSO4, 0.50 gr MgSO4.7H2O, 5.0 gr Na2S2O3 and dissolved in $1000 \mathrm{ml}$ of distilled water with $\mathrm{pH}$ 8.0. The media was sterilized and poured into $50 \mathrm{ml}$ erlenmeyer as much as $20 \mathrm{ml}$ each. The waste samples were then diluted through a serial dilution of 10-2 and inoculated into $1 \mathrm{ml}$ of Thiobacillus broth media. Erlenmeyer was incubated in an incubator at $30^{\circ} \mathrm{C}$ for 25 days. Bacterial growth is characterized by the presence of turbidity and biofilms found on the surface of the media and erlenmeyer walls.

\section{Screening of Sulfur Bacteria}


The isolates previously grown on the Thiobacillus broth medium with initial $\mathrm{pH} 8.0$ then measured the final $\mathrm{pH}$ using a $\mathrm{pH}$ meter. The isolate screening process was carried out by selecting isolates capable of reducing $\mathrm{pH}$ from 8.0 to .03 .0 . The selected isolates were then grown on solid Thiobacillus agar containing 0.40 gr (NH4) 2SO4, 4.0 gr KH2PO4, 0.25 gr $\mathrm{CaCl} .2 \mathrm{H} 2 \mathrm{O}$, 0.01 gr FeSO4, 0.50 gr $\mathrm{MgSO} 4.7 \mathrm{H} 2 \mathrm{O}, 5.0$ gr Na2S2O3, and 12.50 gr to be original, in $1000 \mathrm{ml}$ of aquades with $\mathrm{pH} 8.0$ to be further characterized.

\section{Morphological and Biochemical Characterization}

Characterization was carried out on isolates grown on Thiobacillus agar media, including Gram staining and several biochemical tests such as catalase test, oxidase test, motility test, starch hydrolysis, SIM (Sulfide Indole Motility) test and TSIA test (Triple Sugar Iron Agar) .

\section{a. TSIA Test and H2S Production}

The suspected SOB isolates that have been screened, are grown on Triple Sugar Iron Agar (TSIA) media, then incubated at $300 \mathrm{C}$ for $24-48$ hours. Then the color changes in the media were observed, the positive results of sugar fermentation were marked by changes in the color of the media from red to yellow. While the positive results of $\mathrm{H} 2 \mathrm{~S}$ production are shown to change color from yellow to black.

\section{b. Motility Test}

The suspected SOB isolate that has been screened is grown on Sulfate Indol Motility (SIM) media, by inserting an ose needle containing bacterial isolates on the media. Then observed changes in the media, positive results are shown with certain patterns on the media as long as the puncture results.

\section{c. Indol Test}

The suspected SOB isolates that have been screened are grown on Sulfate Indol Motility (SIM) media, then incubated at 300C for $24-48$ hours. Positive results are indicated by pink colored rings at the top of the media after being pressed with Kovac's reagent.

\section{d. Starch Hydrolysis Test}

Bacteria that have been isolated and seen growth in the culture are poured lugol solution and left for several minutes. Then observed the color changes that occur around the colony. Positive results are indicated by the formation of clear zones around the colony after iodine drops.

\section{e. Catalase Test}


The suspected SOB isolates that have been screened are reviewed on sterile glass objects. Then drop $3 \% \mathrm{H} 2 \mathrm{O} 2$, observe whether there is a bubble. Positive results are indicated by the presence of gas bubbles.

\section{f. Oxidase Test}

SOB suspected isolates that have been screened, taken using an ose and applied to a piece of filter paper. Then drop 1-2 drops of oxidase reagent in bacterial culture. Then observe changes in color in bacterial culture. Bluish purple formation shows positive results.

\section{Identification of Bacteria}

After morphological and biochemical characterization, identification of bacterial species was carried out using the book Bergey's Manual of Determinative Bacteria (Holt et al. 1994) and the Bergey's Manual of Systematic Bacteria Vol 2A (Brenner et al., 1923).

\section{Results and Discussion}

Screening of Sulfur Bacteria from Rubber Waste

A total of 2 isolates of sulfur oxidizing bacteria (SOB) were successfully obtained from liquid waste from the rubber industry in Jambi Province. Both isolates were isolates of AE01 and AE02, respectively. The results of SOB bacterial culture showed growth in the medium of Thiobacillus broth which was characterized by the formation of mucous layers (biofilms) on the surface of the media after incubation for \pm 25 days (Rosa, et.al, 2017).

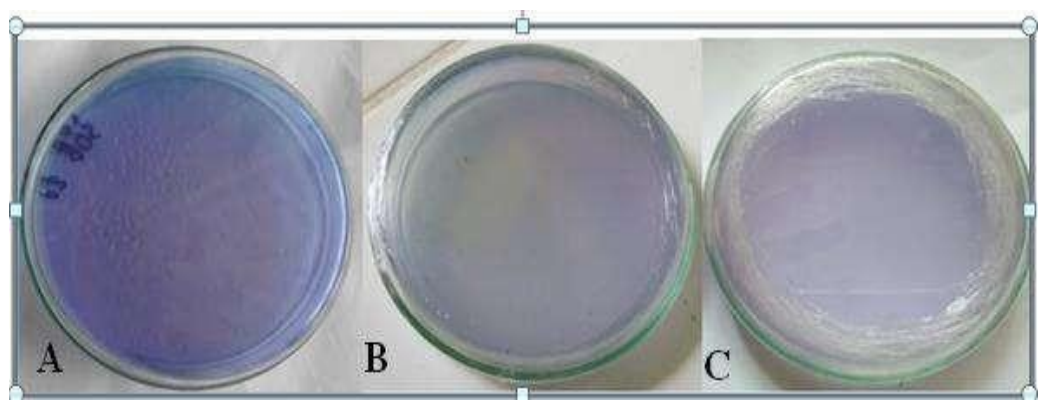

Figure 1. Culture of sulfur oxidizing bacterial isolates (SOB) in starkey media with Bromocresol purple A). Medium before bacterial isolation B). Growth of AE01 isolate C. AE02 isolate

One characteristic of $\mathrm{SOB}$ bacteria was its ability to reduce $\mathrm{pH}$. The $\mathrm{pH}$ value greatly affects the metabolic activity of SOB bacteria in oxidizing the substrate where it grows. The two isolates obtained from rubber wastewater were also tested for metabolic activity. The results of the tests conducted indicate that there had been a decrease in $\mathrm{pH}$ on the medium of Thiobacillus broth. This can be seen in the decreasing $\mathrm{pH}$ of media which was originally 8.0 to 2.63 (AE01) and 
2.61 (AE02). Dara (2000) states that SOB bacteria are always found to live at low $\mathrm{pH}$ and are found mostly in soil and water containing sulfate.

According to Donati et al. (1996), pH reduction on selective media of Thiobacillus broth is caused by the production of sulfuric acid which causes the $\mathrm{pH}$ of the previously alkaline media to turn sour due to the growth of SOB bacteria. Nurseha and Djajakirana (2004) also add that SOB bacteria generally get energy from the oxidation of one or more reduction of sulfur compounds. Some examples of SOB bacteria such as Thiobacillus ferooksidans add energy by oxidizing ferro to ferric.

SOB bacteria carry out oxidation processes directly or indirectly. Regusa and Medgwick (1990) concluded that microorganisms successfully dissolve heavy metals and sulfides directly through dependence on metabolism or indirectly with products of their metabolism. $\mathrm{pH}$ reduction tests carried out on SOB bacteria have also been reported by several previous studies (Donati et al. 1996; Vidyalakshmi and Sridar, 2006; Priyanka, Sivaji and Sridar, 2014 and Sajjad et al. 2016). Ferrous sulphate contained in the media will be rapidly oxidized by acidophilic microbes when there is oxygen and/or ferric iron in the environment (Sajjad et al.2016).

These microbes are acidic (acidophilic), using source $\mathrm{C}$ from inorganic materials (lithotrophs or muscrof) and using energy sources from oxygen (Wentzel, 2004). The T.ferrooxidans species, known as chemolytotrophy and synthesizing its cells from carbon obtained enzymatically from $\mathrm{CO} 2$, turned out to be able to use organic carbon in a limited way (Bacelar-Nicolau and Johnson, 1999). The presence of BOS will drive AMD to 500,000-1,000,000 times compared to geochemical reactions (Mills, 2004) so that in this case the microbial group is very detrimental to the environment in which they live.

Table 3. Characteristics of Morphology of SOB bacterial isolates originating from rubber factory waste

\begin{tabular}{|c|c|c|c|c|c|c|c|c|}
\hline \multirow{2}{*}{ No } & \multirow{2}{*}{$\begin{array}{l}\text { Code } \\
\text { Isolate }\end{array}$} & \multicolumn{6}{|c|}{ Morphology } & \multirow{2}{*}{$\begin{array}{l}\text { Optical } \\
\text { characteristic }\end{array}$} \\
\hline & & Colour & Form & Size & Elevation & Surfaces & Margin & \\
\hline 1 & AE01 & grey & filamentous & Medium & Flate & $\begin{array}{l}\text { smooth- } \\
\text { shiny }\end{array}$ & $\begin{array}{l}\text { filamen } \\
\text { tous }\end{array}$ & Transparance \\
\hline 2 & AE02 & white & round & small & Flate & smooth & Full & $\begin{array}{l}\text { Partly } \\
\text { transparance }\end{array}$ \\
\hline
\end{tabular}




\section{Characteristics of morphology, physiological properties and biochemical activity of bacteria}

The two bacterial isolates suspected of SOB were then characterized based on morphological characteristics, physiological properties and biochemical activities. This is an important part of bacterial identification (Berge's Manual of Systematic Bacteriology).

The two isolates showed different characteristics (Table 3). Differences in these characteristics include colony color, shape, colony size, elevation, surface appearance and margin. However, the optical characteristic test performed on the two isolates showed the same results, They were Translucent. Pelczar and Chan (1988) state that each genus of bacteria will generally form its own characteristics but some of the characteristics that are also shown to be possible will be the same.

The process of identification of bacteria was carried out after going through several kinds of biochemical tests such as the Gram staining test (Figure 2), biochemical tests (Table 4) which include: catalase test, SIM test to measure indole production and motility, TSIA test to measure $\mathrm{H}_{2} \mathrm{~S}$ production, gas production, and the ability of bacteria to ferment three types of sugar, $\mathrm{pH}$ reduction test and amylum hydrolysis test (starch hydrolysis).

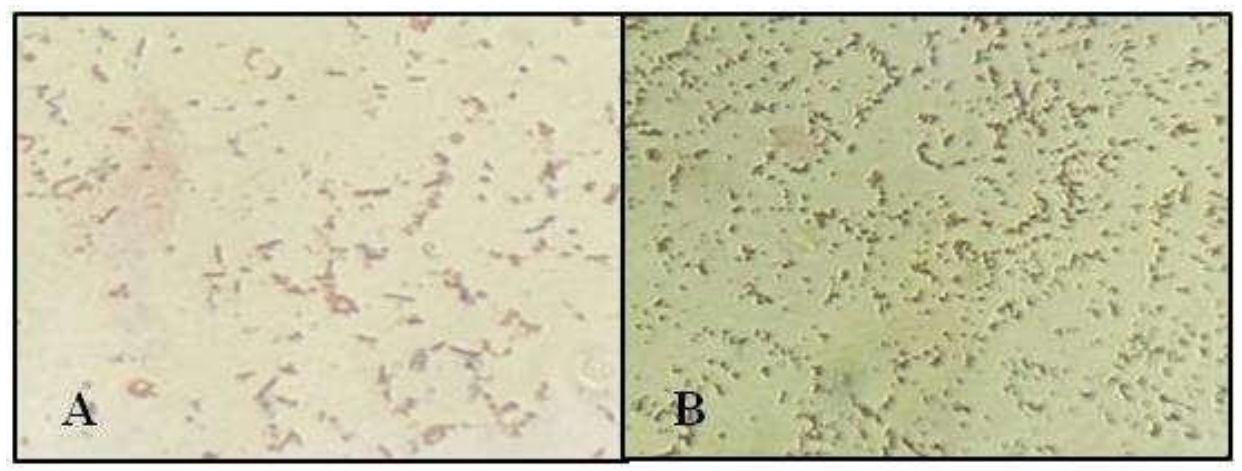

Figure 2. The staining results of the two sulfur oxidizing bacterial isolates (SOB). A) Isolate AE01, B). Isolate AE02

Based on the characteristics of the isolates in Table 4, it was assumed that AE01 isolate was the Thiobacillus ferrooxidans. This is because the characteristics possessed by the bacteria Thiobacillus ferrooxidans were in accordance with the characteristics possessed by AE01. The characteristics include the same life ability in the range of $\mathrm{pH}$ 1.3-4.5; classified as bacil Gram negative bacteria; and the isolates obtained were classified as facultative aerobes. Robertson \& Kuenen (2005) states that bacteria with these characteristics generally use the oxidation results from $\mathrm{Fe} 2+$ and reduce sulfur as their energy source, as well as ammonium and nitrate as their nitrogen source. This bacterium also needs oxygen for life. This is also in accordance with the 
test results that have been carried out. Nevertheless, further investigation at the molecular level using rRNA is needed to obtain accurate data on the species obtained.

Microorganisms will use energy produced from the oxidation / reduction process of metals or other harmful compounds for growth. Thiobacillus is able to reduce $\mathrm{pH}$ to the range 5.6-6.2 to 2.6- 2.8, and utilize sulfur and thiosulphate as its energy source (Vidyalakhsmi \& Sridar, 2006). According to Sajjad et al. (2016), most sulfur bacteria (sulfur-oxidizing bacteria) are a group of bacteria belonging to the genus Thiobacillus, Thiomicrospira, Thiothrix, Desulforomonas and Achromatium. However, sulfur oxidation is not only limited by true bakterisulfur but can also be carried out by other heterotrophic bacteria isolated from soil or aquatic environments which are capable of carrying out the same oxidation mechanism (Das et al. 1996).

Table 4. Characteristics of Physiological Properties and Biochemical Activities Bacterial isolates of SOB bacteria originating from rubber factory wastes

\begin{tabular}{|c|c|c|c|}
\hline No & Physiological Test & AE01 & AE02 \\
\hline 1 & Form & Bacil & Coccus \\
\hline 2 & Gram stain & negative & negative \\
\hline 3 & Catalase & - & - \\
\hline 4 & Motility & + & + \\
\hline 5 & Gas production & + & - \\
\hline 6 & $\mathrm{H} 2 \mathrm{~S}$ production & - & - \\
\hline \multirow[t]{2}{*}{7} & TSIA & Alkaline slant & Acid slant \\
\hline & & Alkaline butt & Alkaline butt \\
\hline 8 & Bromocresol purple & + & - \\
\hline 9 & $\mathrm{pH}$ reduction & good & good \\
\hline
\end{tabular}

The use of SOB bacteria has been widely used. Handayani (1997) reports that, SOB microorganisms that have the potential to oxidize iron and sulfur include Thiobacillus ferrooxidans, Thiobacillus thiooxidans, Leptospirillum ferrooxidans and genus from Sulfolobus 
such as S. acidocaldarius. Thiobacillus Ferrooxidans is also reported as one of the safest and most environmentally friendly types of alternative bacteria for coal desulfurization. Thiobacillus ferooxidans has the ability to oxidize iron and sulfur.

\section{Conclusion}

Based on the research that has been done, it can be concluded that:

a. It has been found 2 isolates of $\mathrm{SOB}$ bacteria derived from liquid waste from rubber plantations. However, the researchers did not succeed in finding SOB bacterial isolates originating from paper industry wastewater.

b. From the identification carried out, the two bacterial isolates were thought to belong to SOB bacteria which were able to oxidize sulfur as a carbon source. The isolate with the AE01 isolate code is thought to be a bacterium with the species Thiobacillus ferrooxidans.

\section{Acknowledgment}

A big thank you to the Faculty of Science and Technology and the University of Jambi Institute of Research and Community Services who have provided research funds so that this research can be carried out.

\section{References}

[1] Bacelar-Nocolau, P \& D.B. Johnson, 1990. Leaching of Pyrite by Acidophilic Heterotrophic Iron-Oxidizing Bacteri in ure and Mixed Cultures. Applied and Environtmental Microbiology. 65(2): 585-590

[2] Brenner, D.J., Krieg, N.R., dan Staley, J.T. 1923. Genus Acidithiobacillus. Dalam: Bergey's Manual of Systematic Bacteriology Vol. 2A, 2nd Ed. USA: Springer.

[3] Dara ICM. 2000. Populasi bakteri Thiobacillus ferooxidans di kolom tanah yang berasal dari sedimen berpirit dari delta telang, Musi Banyuasin, Sumatera Selatan yang mengalami pengeringan dan pencucian [tesis]. Program Pascasarjana Institut Pertanian Bogor-Bogor.

[4] Das, S.K., A.K. Mishra, B.J. Tindall, F.A. Rainey and E. Stackerbrandt. 1996. Oxidation of Thiosulfate by A New Bacterium, Bosea thiooxidans (strain BI-42) gen. nov., sp. nov.: Analysis of Phylogeny Based on Chemotaxanomy on 16S Ribosomal DNA Sequencing. International Journal of Systematic Bacteriology, 64: 981-987.

[5] Donati, E., Curutchet, G., Pogliani, C., dan Tedesco, P. 1996. Bioleaching of Covellite Using Pure and Mixed Cultures of Thiobacillus ferrooxidans and Thiobacillus thiooxidans. Process Biochemistry, 31(2): 129-134.

[6] Handayani, S. 1997. The Immobilization of soluble metals by bacterial walls. Indon. Min J. 3(1): 31-36 
[7] Kantachote, D., dan Innuwat, W. 2004. Isolation of Thiobacillus sp. for Use in Treatment of Rubber Sheet Wastewater. Songklanakarin Journal of Science and Technology, 26(5): 649-657.

[8] Nurhayati dan Mahmudin, I. 2012. Pengolahan Limbah Cair Kertas dan Pulp dengan Menggunakan Aerasi dan Tekanan Filter Karbon Aktif. Jurnal Ilmiah Fakultas Teknik LIMIT'S, 8(1): 14-26.

[9] Nurseha, Djajakirana G. 2004.Isolasi dan uji aktivitas bakteri asidofilik pengoksidasi besi dan sulfur dari ekosistem air hitam di Kalimantan Tengah. Jurnal Tanah dan Lingkungan. 6(2): 51-56.

[10] Pelczar, M.J. dan E.C. Chan. 1988. Dasar-dasar Mikrobiologi. Jakarta: Universitas Indonesia Press.

[11] Priyanka, S., Sivaji, M., dan Sridar, R. 2014. Isolation and Characterization of A Novel Multifunctional Sulphur Oxidizing Bacterium (SOB) and Its Use As Biofertilizer. International Science Journal, 1(1): 28-34.

[12] Rojas-Avelizapa, N.G., Gomez-Ramirez, M., Hernandez-Gama, R., Aburto, J., dan Garciade Leon, R. 2013. Isolation and Selection of Sulfur-oxidizing Bacteria for the Treatment of Sulfur-containing Hazardous Wastes. Chemical and Biochemical Engineering, 27(1): 109-117.

[13] Sajjad, W., Bhatti, T.M., Hasan, F., Khan, S., Badshah, M., Naseem, A.A., dan Shah, A.A.2016. Characterization of Sulfur-oxidizing Bacteria Isolated from Acid Mine Significance.

[14] Suwardin, D. 1989. Teknik pengendalian limbah industri karet. Jurnal Karet 4 (2): 2834.

[15] Vidyalakshmi, R., dan Sridar, R. 2006. Isolation and Characterization of Sulphur Oxidizing Bacteria. Journal of Culture Collections, 5: 73-77.

[16] Yuliani, D., Yeni, E, M. 2014. Integrasi Teknologi Pengendalian Penyakit Blas pada Tanaman Padi diLahan Sub-Optimal. Prosiding Seminar Nasional Lahan Suboptimal. Palembang. 